\title{
Impact of Modified Atmosphere Packaging on Nutritive Values and Sensory Qualities of Fresh Maize (Zea mays L.) Under Tropical Ambient Storage Condition
}

\author{
Florence Abolaji Bello ${ }^{1}$, , Isaac Babatunde Oluwalana ${ }^{2}$ \\ ${ }^{1}$ Department of Food Science and Technology, University of Uyo, Uyo, Nigeria \\ ${ }^{2}$ Department of Food Science and Technology, Federal University of Technology, Akure, Nigeria
}

Email address:

florenceabello@uniuyo.edu.ng (F. A. Bello)

*Corresponding author

\section{To cite this article:}

Florence Abolaji Bello, Isaac Babatunde Oluwalana. Impact of Modified Atmosphere Packaging on Nutritive Values and Sensory Qualities of Fresh Maize (Zea mays L.) Under Tropical Ambient Storage Condition. International Journal of Nutrition and Food Sciences. Vol. 6, No. 1, 2017, pp. 19-24. doi: 10.11648/j.ijnfs.20170601.14

Received: November 26, 2016; Accepted: December 16, 2016; Published: January 14, 2017

\begin{abstract}
Effect of film packaging on fresh yellow maize (Zea mays L.) on the cob after harvesting was tested. Proximate, mineral and sensory qualities of fresh maize samples subjected to passive modified atmosphere packaging (PMAP) and unpackaged samples at day $1,2,3$ and 4 of storage at tropical ambient temperature $\left(28 \pm 2^{\circ} \mathrm{C}\right)$ and $80 \% \mathrm{RH}$ were carried out. The samples were compared with freshly harvested maize (FHM) which served as control. Results of proximate composition showed that the sample T1 (undehusked maize) maintained its moisture content at day 1 and 2 of storage and had the highest total sugar content when compared to other stored samples. Mineral composition showed higher contents of potassium, phosphorus, sodium and magnesium in control sample. Mineral content of T1 (undehusked maize) was not different significantly $(\mathrm{p}<0.05)$ from the control. T2 (dehusked maize) and PMAP samples had the lowest values due to their rate of deterioration at day 3 and 4 of storage. The sensory evaluation result showed the control sample to be the most preferred and followed by $\mathrm{T} 1$ in all the quality attributes (colour, taste, aroma and overall acceptability) evaluated. Due to the fast deterioration of fresh maize qualities after harvesting, it can therefore be concluded that PMAP had no impact in extending the storage life of fresh maize at ambient temperature.
\end{abstract}

Keywords: Ambient Temperature, Composition, Dehusked, Fresh Maize, Packaging, Postharvest

\section{Introduction}

Maize, Zea mays L., also referred to as corn is the most important cereal crop in the world after wheat and rice with regard to cultivated areas and total production. It is widely cultivated in the tropics [1] and a dietary staple for more than 200 million people in sub tropics and temperate regions of the world including Africa, America and Asia [2, 3]. It is cultivated both as rain-fed and under irrigation in the savannah agroecological zone of Nigeria, where its production has moved from that of subsistence cultivation to commercial cultivation [4]. Maize is an annual crop with a height range of 8-10 meters and it is characterized by an erect green stalk. General classes of maize include flint, pop, flour, dent, and sweet maize. The terms "common," "normal," or "typical" maize generally refer to dent and flint varieties. Depending on environmental, cultural, and genetic parameters, maize kernels can vary in colour (white, yellow, orange, red and black), quantity (300-1000 kernels per ear), weight (190-300 g per 1000 kernels), spatiality (12-16 kernels per row) and nutrient composition [2, 5].

Yellow dent maize which currently dominates the South Western part of Nigeria has a greater demand compare to white varieties. It is eaten as roasted and enjoy alongside with African pear or coconut and also in boiled form [6]. Its consumption is very high during every annual harvest season. Generally, maize is a rich source of carbohydrates, vitamins, proteins and minerals. It has a horny endosperm and more carotenoids (41.33-179.93\%), which are the source of yellow colour in maize [7]. Sweetness and characteristic aroma 
which make up the sensory attributes are the most important indicators of shelf life from the consumer's point of view [8]. Fresh produce especially freshmaize has a very short shelf life and its nutritional composition undergoes significant changes immediately after harvesting as a result of metabolic reactions $[9,10]$. Shelf life of agricultural commodities can be extended by several methods such as modified atmosphere storage, controlled atmosphere storage, chemical treatments and irradiation among others [11]. This study was therefore carried out to test theeffectiveness of modified atmosphere packaging on the postharvest nutritional and sensory qualities of freshly harvested yellow maize on the cob at ambient temperature storage.

\section{Materials and Methods}

\subsection{Materials}

Freshly harvested ears of open pollinated variety (SUWAN 1-SR) of normal yellow maize on the cob was obtained from the Research farm of the Federal University of Technology Akure (FUTA) and Low Density Polyethylene (LDPE) of two different gauges $(25$ and $30 \mu \mathrm{m})$ with $34 \mathrm{~cm} \times 14.5 \mathrm{~cm}$ in area were used. Fresh maize were dehusked by hand and randomly selected for immediate analysis (control) while the remaining fresh maize were grouped into six lots: undehusked maize (T1), dehusked maize (T2), undehusked maize packaged with $25 \mu \mathrm{m}$ LDPE (T3), dehusked maize packaged with $25 \mu \mathrm{m}$ LDPE (T4), undehusked maize packaged with $30 \mu \mathrm{m}$ LDPE (T5) and dehusked maize packaged with $30 \mu \mathrm{m}$ LDPE (T6). All the PMAP samples were heat sealed using an impulse sealer (MEC, China). Samples were then transferred into a chamber set at $28 \pm 2^{\circ} \mathrm{C}$ and $80 \%$ RH maintained for 4 days.

\subsection{Methods}

\subsubsection{Proximate Analysis}

Samples were taken on daily basis during storage for proximate composition using the recommended method of [12]. The moisture content of the various samples was determined on drying at $105^{\circ} \mathrm{C}$ in an oven until a constant weight was attained. The difference ininitial and final weights of the sample was expressed in percentage moisture. Micro-Kjeldahl method was employed to determine the total nitrogen and the crude protein was calculated based on nitrogen conversion factor of 6.25. Crude fat was extracted with petroleum ether using the Soxhlet method, crude fibre and ash contents (gravimetric) were determined. Total crude carbohydrate was estimated as follows: Total crude carbohydrates $(\%)=100-(\%$ Ash $+\%$ Crude protein $+\%$ Crude lipid $+\%$ Crude fibre). Total sugar was determined using phenol-sulphuric acid method [13].

\subsubsection{Mineral Analysis}

The maize samples were ashed at $550^{\circ} \mathrm{C}$. The ash was boiled with $10 \mathrm{ml}$ of $20 \% \mathrm{HCl}$ in a beaker and then filtered into a $100 \mathrm{ml}$ standard flask. This was made up to the mark with deionized water and the minerals were determined from the resulting solution using the method described by [11]. Sodium $(\mathrm{Na})$ and Potassium $(\mathrm{K})$ were determined using the standard flame emission photometer. $\mathrm{NaCl}$ and $\mathrm{KCl}$ were used as the standards. Phosphorus was determined calorimetrically using the spectronic 20 (Gallenkamp, UK) with $\mathrm{KH}_{2} \mathrm{PO}_{4}$ as the standard. Calcium (Ca), Magnesium $(\mathrm{Mg})$ and Iron $(\mathrm{Fe})$ were determined using Atomic Absorption Spectrophotometer (AAS Model SP9). All values were expressed in $\mathrm{mg} / 100 \mathrm{~g}$.

\subsubsection{Sensory Evaluation}

The stored packaged and unpackaged maize samples, and fresh maize samples harvested daily for comparison purpose (control) were boiled for $10 \mathrm{~min}$ and were coded before presenting to 20 member panelists (postgraduate students of FUTA) for evaluation. The sensory evaluation was conducted in a standard sensory laboratory where each of the panelists was positioned in a separate cubicle to avoid interferences. All indices were measured using a 9 point Hedonic scale from 1 to 9 , where a score of 9 represents extremely like and a score of 1 represents extremely dislike [14].

\subsubsection{Statistical Analysis}

All experiments were done in triplicate. Data generated were analysed using SPSS version 20.0 software. One way analysis of variance (ANOVA) was employed to study the difference between means and where differences existed $(\mathrm{p}<0.05)$. Duncan's New Multiple Range Test was used to separate the means.

\section{Results and Discussion}

\subsection{Changes in Chemical Composition (Proximate and Sugar Content) of Packaged and Unpackaged Fresh MaizeDuring Storage}

The result of proximate composition of packaged and unpackaged fresh yellow maize on the cobs stored at ambient temperature $\left(28 \pm 2^{\circ} \mathrm{C}\right)$ from day 1 to 4 is presented in Table 1 . Moisture contents were in the range of 54.04-63.50\% and $51.48-65.85 \%$ on day 1 and 2 of storage, respectively. Samples T1 (unpackaged undehusked maize) and T2 (unpackaged dehusked maize) were significantly $(\mathrm{p}<0.05)$ lowered than the control $(61.13 \%)$ throughout the storage duration. Passive Modified Atmosphere (PMAP) samples (T3, T4, T5 and T6) had significantly $(\mathrm{p}<0.05)$ higher values than the control and the unpackaged samples (T1 and T2) on day 1 and 2 of storage. Moisture content for PMAP samples was not determined on day 3 and 4 due to the visible appearance of microbes. Moisture content is a very important factor not only in preharvest life of fresh maize but also during postharvest storage duration. Moisture content affects the appearance, textural characteristics and the chemical profile of fresh maize. In the present study, presence and absence of husks, packaging film with the interaction of storage duration and temperature had significant effects on moisture content of freshly harvested maize on the cob. 
Increase moisture content of PMAP samples as the storage duration progressed could be as a result of metabolic reactions during respiration. This probably encourages the proliferation of microbes. Ambient storage temperature had a great effect on dehusked maize which led to its dented appearance and shrinkage. The main reason for moisture loss is transpiration [8] and occurs primarily in the husks which in turn incur moisture loss from kernels and cobs in the form of water vapour $[15,16]$. Ash $(3.93 \%)$, crude protein $(13.12 \%)$, crude fat $(4.78 \%)$, crude fibre $(5.43 \%)$ and carbohydrate $(72.74 \%)$ were recorded for the control sample and thesewere similar to the finding of [17]. Significant differences $(p<0.05)$ existed among the treatments. The carbohydrate content ranged from $72.23-73.07 \%$ and $71.57-73.86 \%$ on day 1 and 2 of storage, respectively. The highest content was recorded for dehusked maize samples (T2) on day $3(75.22 \%)$ and 4 $(77.72 \%)$ of storage. It was observed that $\mathrm{T} 1$ and $\mathrm{T} 2 \mathrm{had}$ higher carbohydrate contents than the control and PMAP samples. A decreasing trend in ash, crude protein, crude fat and crude fibre contents were noticed in all the treatments from day 1 to 4 of storage except T1 which was not significantly affected by the storage temperature.

Table 1. Proximate composition of packaged and unpackaged fresh maize stored at $28 \pm 2{ }^{\circ} \mathrm{C}$.

\begin{tabular}{|c|c|c|c|c|c|c|c|}
\hline SD & Sample & Moisture & Ash & Crude & Crude fat & Crude & Carbohy \\
\hline (day) & code & content $(\%)^{*}$ & $(\%)$ & protein $(\%)$ & $(\%)$ & fibre (\%) & drate(\%) \\
\hline 0 & FHM & $61.13 \pm 1.32^{\mathrm{d}}$ & $3.93 \pm 0.02^{\mathrm{a}}$ & $13.12 \pm 0.59^{\mathrm{a}}$ & $4.78 \pm 0.13^{\mathrm{c}}$ & $5.43 \pm 0.34^{\mathrm{a}}$ & $72.74 \pm 1.75^{\text {ef }}$ \\
\hline \multirow{5}{*}{1} & $\mathrm{~T} 1$ & $58.40 \pm 1.70^{\mathrm{e}}$ & $3.92 \pm 0.28^{\mathrm{a}}$ & $13.04 \pm 0.34^{\mathrm{a}}$ & $4.74 \pm 0.14^{\mathrm{c}}$ & $5.38 \pm 0.20^{\mathrm{a}}$ & $72.92 \pm 0.60^{\mathrm{e}}$ \\
\hline & $\mathrm{T} 2$ & $54.04 \pm 0.82^{\mathrm{f}}$ & $3.86 \pm 0.19^{b}$ & $13.10 \pm 0.34^{\mathrm{a}}$ & $4.65 \pm 0.06^{c}$ & $5.32 \pm 0.38^{\mathrm{a}}$ & $73.07 \pm 0.52^{\mathrm{e}}$ \\
\hline & $\mathrm{T} 3$ & $62.40 \pm 1.10^{\mathrm{d}}$ & $3.61 \pm 0.11^{\mathrm{d}}$ & $12.34 \pm 0.17^{\mathrm{b}}$ & $6.40 \pm 0.29^{b}$ & $5.23 \pm 0.57^{\mathrm{b}}$ & $72.42 \pm 0.80^{f}$ \\
\hline & $\mathrm{T} 4$ & $61.10 \pm 0.51^{\mathrm{d}}$ & $3.66 \pm 0.13^{\mathrm{d}}$ & $12.52 \pm 0.37^{b}$ & $6.31 \pm 0.35^{\mathrm{b}}$ & $5.28 \pm 0.22^{\mathrm{b}}$ & $72.23 \pm 0.19^{f}$ \\
\hline & $\mathrm{T} 5$ & $63.50 \pm 0.60^{\mathrm{c}}$ & $3.72 \pm 0.08^{\mathrm{c}}$ & $12.25 \pm 0.23^{\mathrm{c}}$ & $6.50 \pm 0.26^{\mathrm{b}}$ & $5.21 \pm 0.52^{\mathrm{b}}$ & $72.31 \pm 0.41^{\mathrm{f}}$ \\
\hline \multirow{6}{*}{2} & $\mathrm{~T} 1$ & $52.37 \pm 0.31^{\mathrm{f}}$ & $3.81 \pm 0.24^{\mathrm{b}}$ & $12.83 \pm 0.25^{\mathrm{b}}$ & $4.39 \pm 0.13^{\mathrm{c}}$ & $5.35 \pm 0.09^{\mathrm{a}}$ & $73.62 \pm 0.76^{\mathrm{d}}$ \\
\hline & $\mathrm{T} 2$ & $51.48 \pm 0.62^{\mathrm{f}}$ & $3.75 \pm 0.54^{\mathrm{c}}$ & $12.96 \pm 0.23^{b}$ & $4.15 \pm 0.24^{\mathrm{e}}$ & $5.28 \pm 0.25^{\mathrm{b}}$ & $73.86 \pm 0.91^{\mathrm{d}}$ \\
\hline & $\mathrm{T} 3$ & $65.45 \pm 0.76^{\mathrm{a}}$ & $3.54 \pm 0.22^{\mathrm{e}}$ & $11.96 \pm 0.29^{\mathrm{d}}$ & $7.52 \pm 0.19^{\mathrm{a}}$ & $5.15 \pm 0.35^{\mathrm{c}}$ & $71.83 \pm 0.19^{g}$ \\
\hline & $\mathrm{T} 4$ & $64.50 \pm 0.70^{\mathrm{b}}$ & $3.40 \pm 0.25^{\mathrm{f}}$ & $12.28 \pm 0.35^{\mathrm{c}}$ & $7.54 \pm 0.32^{\mathrm{a}}$ & $5.21 \pm 0.32^{\mathrm{b}}$ & $71.57 \pm 0.13^{g}$ \\
\hline & $\mathrm{T} 5$ & $65.85 \pm 0.31^{\mathrm{a}}$ & $3.51 \pm 0.41^{\mathrm{e}}$ & $11.83 \pm 0.29^{\mathrm{d}}$ & $7.38 \pm 0.20^{\mathrm{a}}$ & $5.16 \pm 0.36^{\mathrm{c}}$ & $72.12 \pm 0.53^{\mathrm{g}}$ \\
\hline & T6 & $64.60 \pm 0.57^{\mathrm{b}}$ & $3.48 \pm 0.12^{\mathrm{f}}$ & $12.20 \pm 0.40^{\mathrm{c}}$ & $7.48 \pm 0.14^{\mathrm{a}}$ & $5.19 \pm 0.44^{\mathrm{c}}$ & $71.65 \pm 0.35^{\mathrm{g}}$ \\
\hline \multirow{5}{*}{3} & $\mathrm{~T} 1$ & $49.45 \pm 0.36^{\mathrm{fg}}$ & $3.67 \pm 0.22^{\mathrm{d}}$ & $12.72 \pm 0.60^{b}$ & $4.26 \pm 0.27^{d}$ & $5.32 \pm 0.19^{\mathrm{a}}$ & $74.03 \pm 0.72^{\mathrm{c}}$ \\
\hline & $\mathrm{T} 3$ & ND & ND & ND & ND & ND & ND \\
\hline & $\mathrm{T} 4$ & ND & ND & ND & ND & ND & ND \\
\hline & $\mathrm{T} 5$ & ND & ND & ND & ND & ND & ND \\
\hline & T6 & ND & ND & ND & ND & ND & ND \\
\hline \multirow{6}{*}{4} & $\mathrm{~T} 1$ & $46.64 \pm 0.63^{g}$ & $3.54 \pm 0.28^{\mathrm{e}}$ & $10.52 \pm 0.31^{\mathrm{b}}$ & $4.01 \pm 0.40^{\mathrm{e}}$ & $4.21 \pm 0.22^{\mathrm{d}}$ & $77.63 \pm 0.30^{\mathrm{a}}$ \\
\hline & $\mathrm{T} 2$ & $41.61 \pm 0.40^{\mathrm{h}}$ & $3.43 \pm 0.18^{\mathrm{f}}$ & $10.84 \pm 0.28^{\mathrm{a}}$ & $3.94 \pm 0.32^{\mathrm{e}}$ & $4.16 \pm 0.30^{\mathrm{e}}$ & $77.72 \pm 0.15^{\mathrm{a}}$ \\
\hline & $\mathrm{T} 3$ & ND & ND & ND & ND & ND & ND \\
\hline & $\mathrm{T} 4$ & ND & ND & ND & ND & ND & ND \\
\hline & $\mathrm{T} 5$ & ND & ND & ND & ND & ND & ND \\
\hline & T6 & ND & ND & ND & ND & ND & ND \\
\hline
\end{tabular}

Different letters denote significant difference $(\mathrm{p}<0.05)$ within each column. $\% *=\%$ wet basis, SD=Storage Duration, FHM= Freshly Harvested Maize, $\mathrm{T} 1=$ Undehusked maize, T2=Dehusked maize, T3=Undehusked maize packaged with $25 \mu \mathrm{m}$ gauge LPDE, T4= Dehusked maize packaged with $25 \mu \mathrm{m}$ gauge LDPE, T5= Undehusked maize packaged with $30 \mu \mathrm{m}$ gauge LDPE, T6= Dehusked maize packaged with $30 \mu \mathrm{m}$ gauge LDPE, ND= Not Determined due to observations of microbial growth. Values are means \pm SD of three determinations.

Deterioration observed in PMAP samples on day 3 and 4 of storage might be attributed to heat generated by the respiration of fresh maize inside the packaging material at storage. The total sugar content of packaged and unpackaged fresh maize is shown in Table 2. The major quality characteristic of fresh maize is sugar content and therefore kernel sweetness [18]. Sweetness of fresh maize is the most important flavour-related factor. Total sugar content ranged from $11.64-22.64 \mathrm{mg} / \mathrm{g}$ and $10.57-20.78 \mathrm{mg} / \mathrm{g}$ on day 1 and 2 of storage, respectively. Control sample had the highest value of $61.82 \mathrm{mg} / \mathrm{g}$ and was found to be lower than the result of [9] who studied sugar content of Zea mays var. rugosa and this may be as a result of environmental factors or genetic variation. Significant $(p<0.05)$ reduction in sugar contents were noticed in all the treatments from day 2 to 4 of storage. PMAP samples were not determined on day 3 and 4 due to observations of microbial growth.
Table 2. Total sugar content ( $\mathrm{mg} / \mathrm{g}$ ) of packaged and unpackaged fresh maize stored at $28 \pm 2{ }^{\circ} \mathrm{C}$.

\begin{tabular}{llllll}
\hline \multicolumn{7}{l}{ Storage duration (day) } \\
\hline SC & $\mathbf{0}$ & $\mathbf{1}$ & $\mathbf{2}$ & $\mathbf{3}$ & $\mathbf{4}$ \\
\hline T1 & $\left(61.82^{\mathrm{a}}\right)$ & $22.64^{\mathrm{b}}$ & $20.78^{\mathrm{bc}}$ & $16.02^{\mathrm{d}}$ & $14.18^{\mathrm{de}}$ \\
T2 & $\left(61.82^{\mathrm{a}}\right)$ & $19.24^{\mathrm{c}}$ & $18.95^{\mathrm{c}}$ & $12.50^{\mathrm{e}}$ & $11.78^{\mathrm{f}}$ \\
T3 & $\left(61.82^{\mathrm{a}}\right)$ & $12.88^{\mathrm{e}}$ & $10.57^{\mathrm{f}}$ & $\mathrm{ND}$ & ND \\
T4 & $\left(61.82^{\mathrm{a}}\right)$ & $15.76^{\mathrm{d}}$ & $12.75^{\mathrm{e}}$ & $\mathrm{ND}$ & ND \\
T5 & $\left(61.82^{\mathrm{a}}\right)$ & $11.64^{\mathrm{f}}$ & $10.72^{\mathrm{f}}$ & $\mathrm{ND}$ & ND \\
T6 & $\left(61.82^{\mathrm{a}}\right)$ & $13.84^{\mathrm{e}}$ & $12.24^{\mathrm{e}}$ & ND & ND \\
\hline
\end{tabular}

Different letters denote significant difference $(\mathrm{p}<0.05)$ within each row. $\mathrm{SC}=$ Sample Code, $\mathrm{T} 1=$ Undehusked maize, $\mathrm{T} 2=$ Dehusked maize, T3=Undehusked maize packaged with $25 \mu \mathrm{m}$ gauge LPDE, T4= Dehusked maize packaged with $25 \mu \mathrm{m}$ gauge LDPE, T5= Undehusked maize packaged with $30 \mu \mathrm{m}$ gauge LDPE, T6= Dehusked maize packaged with $30 \mu \mathrm{m}$ gauge LDPE, $\mathrm{ND}=$ Not Determined due to observations of microbial growth. Values in parenthesis are for day 0 (freshly harvested maize) only. Values are means of three determinations. 
Undehusked maize had higher sugar content compared to unpackaged dehusked maize and PMAP samples. This could be as a result of cooling effect of husk and this is in agreement with previous studies of [19] and [20].

\subsection{Changes in Mineral Content of Packaged andUnpackaged Fresh Maize on Cobs During Storage}

The results of selected mineral composition of packaged and unpackaged fresh maize are presented in Table 3. Higher contents of potassium $(801.98 \mathrm{mg} / 100 \mathrm{~g})$, phosphorus (159.77 $\mathrm{mg} / 100 \mathrm{~g})$, sodium $(158.42 \mathrm{mg} / 100 \mathrm{~g})$ and magnesium $(124.95$ $\mathrm{mg} / 100 \mathrm{~g}$ ) were observed in the control sample. This was significantly $(p<0.05)$ higher than the stored samples and it shows that fresh maize is a good source of mineral. Mineral is very essential to the maintenance of human health by supporting healthy immune system, DNA synthesis, wound healing, healthy growth and development of body during adolescence, childhood and pregnancy [21, 22]. However, the value for undehusked maize sample (T1) was significantly similar to the control throughout the storage duration. The least mineral found in control sample were calcium, iron and zinc and further decrease in all the treatment as the storage duration progressed. Significant $(p<0.05)$ differences were noticed among the stored samples from day 1 to 4 of storage. Potassium content ranged from 766.34 (T5)-786.00 mg/100g (T1) on day 1 and 648.51 (T5)-767.33 mg/100g (T1) on day 2 of storage. Higher values $3705.58 \mathrm{mg} / 100 \mathrm{~g}$ and 692.06 $\mathrm{mg} / 100 \mathrm{~g}$ were recorded for $\mathrm{T} 1$ on day 3 and 4 , respectively. A significant $(p<0.05)$ decreasing trends in the mineral contents as storage duration progressed were observed. This result is in accordance with the findings of [23] on storage of plantain at ambient temperature. PMAP samples were not determined on day 3 and 4 of storage as a result of the growth of microorganisms.

Table 3. Mineral content ( $\mathrm{mg} / 100 \mathrm{~g})$ of packaged and unpackaged fresh maize stored at $28 \pm 2{ }^{\circ} \mathrm{C}$.

\begin{tabular}{|c|c|c|c|c|c|c|c|c|}
\hline $\begin{array}{l}\text { SD } \\
\text { (day) }\end{array}$ & $\begin{array}{l}\text { Sample } \\
\text { code }\end{array}$ & $\mathbf{N a}$ & $\mathbf{C a}$ & $\mathbf{K}$ & $\mathbf{F e}$ & Zn & Mg & $\mathbf{P}$ \\
\hline \multirow[t]{3}{*}{0} & FHM & $158.42 \pm 2.29^{\mathrm{a}}$ & $29.70 \pm 1.50^{\mathrm{a}}$ & $801.98 \pm 3.14^{\mathrm{a}}$ & $1.78 \pm 0.23^{\mathrm{a}}$ & $1.98 \pm 0.03^{\mathrm{a}}$ & $124.95 \pm 1.17^{\mathrm{a}}$ & $159.77 \pm 1.17^{\mathrm{a}}$ \\
\hline & $\mathrm{T} 1$ & $152.32 \pm 1.78^{\mathrm{ab}}$ & $29.41 \pm 0.80^{\mathrm{a}}$ & $786.00 \pm 2.49^{\mathrm{a}}$ & $1.74 \pm 0.11^{\mathrm{a}}$ & $1.86 \pm 0.13^{\mathrm{b}}$ & $123.69 \pm 3.37^{\mathrm{a}}$ & $154.25 \pm 2.97^{\mathrm{a}}$ \\
\hline & $\mathrm{T} 2$ & $145.00 \pm 1.45^{\mathrm{b}}$ & $27.70 \pm 0.55^{\mathrm{b}}$ & $783.92 \pm 2.08^{\mathrm{a}}$ & $1.71 \pm 0.24^{\mathrm{a}}$ & $1.81 \pm 0.18^{\mathrm{b}}$ & $122.71 \pm 2.40^{\mathrm{a}}$ & $148.52 \pm 1.73^{b}$ \\
\hline \multirow{5}{*}{1} & $\mathrm{~T} 3$ & $138.67 \pm 2.23^{\mathrm{c}}$ & $25.00 \pm 0.39^{\mathrm{cd}}$ & $781.04 \pm 3.37^{\mathrm{a}}$ & $1.56 \pm 0.48^{\mathrm{c}}$ & $1.72 \pm 0.20^{\mathrm{c}}$ & $119.80 \pm 1.61^{\mathrm{c}}$ & $136.50 \pm 2.60^{c}$ \\
\hline & $\mathrm{T} 4$ & $142.16 \pm 1.05^{\mathrm{b}}$ & $26.50 \pm 0.71^{\mathrm{c}}$ & $784.98 \pm 2.14^{\mathrm{a}}$ & $1.59 \pm 0.05^{\mathrm{c}}$ & $1.70 \pm 0.12^{\mathrm{c}}$ & $120.00 \pm 2.51^{\mathrm{bc}}$ & $140.30 \pm 2.14^{\mathrm{b}}$ \\
\hline & $\mathrm{T} 5$ & $122.55 \pm 1.10^{\mathrm{d}}$ & $20.00 \pm 1.13^{\mathrm{e}}$ & $766.34 \pm 4.17^{b}$ & $1.52 \pm 0.20^{\mathrm{c}}$ & $1.59 \pm 0.29^{d}$ & $117.00 \pm 2.31^{\mathrm{c}}$ & $131.65 \pm 3.25^{\mathrm{c}}$ \\
\hline & $\mathrm{T} 1$ & $150.86 \pm 2.75^{\mathrm{ab}}$ & $26.63 \pm 1.51^{\mathrm{c}}$ & $767.33 \pm 1.79^{b}$ & $1.69 \pm 0.15^{b}$ & $1.70 \pm 0.01^{\mathrm{c}}$ & $122.69 \pm 3.26^{\mathrm{a}}$ & $151.20 \pm 2.04^{\mathrm{a}}$ \\
\hline & $\mathrm{T} 2$ & $140.56 \pm 1.68^{b}$ & $25.72 \pm 0.20^{\mathrm{cd}}$ & $756.47 \pm 4.63^{c}$ & $1.65 \pm 0.27^{\mathrm{b}}$ & $1.68 \pm 0.24^{\mathrm{c}}$ & $120.00 \pm 1.49^{\mathrm{bc}}$ & $135.00 \pm 1.76^{\mathrm{c}}$ \\
\hline \multirow{5}{*}{2} & T3 & $128.71 \pm 1.54^{\mathrm{cd}}$ & $19.92 \pm 1.49^{\mathrm{e}}$ & $710.78 \pm 2.43^{d}$ & $1.49 \pm 0.58^{\mathrm{cd}}$ & $1.34 \pm 0.20^{\mathrm{e}}$ & $116.83 \pm 1.68^{\mathrm{c}}$ & $123.76 \pm 2.85^{\mathrm{d}}$ \\
\hline & $\mathrm{T} 4$ & $113.76 \pm 1.48^{\mathrm{f}}$ & $21.86 \pm 3.71^{\mathrm{d}}$ & $745.76 \pm 5.24^{\mathrm{c}}$ & $1.46 \pm 0.15^{\mathrm{d}}$ & $1.35 \pm 0.29^{\mathrm{e}}$ & $118.87 \pm 2.68^{\mathrm{c}}$ & $130.76 \pm 3.65^{\mathrm{c}}$ \\
\hline & $\mathrm{T} 5$ & $118.71 \pm 1.84^{\mathrm{e}}$ & $19.72 \pm 1.11^{\mathrm{e}}$ & $648.51 \pm 5.41^{\mathrm{e}}$ & $1.43 \pm 0.03^{\mathrm{d}}$ & $1.30 \pm 0.30^{\mathrm{e}}$ & $112.00 \pm 1.11^{\mathrm{d}}$ & $128.52 \pm 3.27^{\mathrm{c}}$ \\
\hline & T6 & $112.00 \pm 2.41^{\mathrm{f}}$ & $19.80 \pm 0.31^{\mathrm{e}}$ & $705.88 \pm 3.22^{\mathrm{d}}$ & $1.48 \pm 0.15^{\mathrm{cd}}$ & $1.34 \pm 0.50^{\mathrm{e}}$ & $113.73 \pm 2.47^{\mathrm{d}}$ & $123.66 \pm 3.41^{\mathrm{c}}$ \\
\hline & $\mathrm{T} 1$ & $142.00 \pm 2.25^{\mathrm{b}}$ & $25.86 \pm 1.71^{\mathrm{cd}}$ & $705.58 \pm 4.83^{\mathrm{d}}$ & $1.60 \pm 0.22^{\mathrm{b}}$ & $1.60 \pm 0.38^{\mathrm{c}}$ & $118.57 \pm 3.64^{c}$ & $145.00 \pm 3.56^{\mathrm{b}}$ \\
\hline \multirow{5}{*}{3} & $\mathrm{~T} 4$ & ND & ND & ND & ND & ND & ND & ND \\
\hline & $\mathrm{T} 5$ & ND & ND & ND & ND & ND & ND & ND \\
\hline & T6 & ND & ND & ND & ND & ND & ND & ND \\
\hline & $\mathrm{T} 1$ & $129.06 \pm 2.65^{\mathrm{cd}}$ & $23.21 \pm 1.22^{\mathrm{d}}$ & $692.06 \pm 4.14^{\mathrm{d}}$ & $1.54 \pm 0.26^{\mathrm{c}}$ & $1.56 \pm 0.26^{\mathrm{c}}$ & $112.47 \pm 2.66^{\mathrm{d}}$ & $142.31 \pm 2.41^{b}$ \\
\hline & $\mathrm{T} 2$ & $131.01 \pm 1.55^{\mathrm{c}}$ & $21.22 \pm 1.30^{\mathrm{d}}$ & $676.85 \pm 5.42^{\mathrm{e}}$ & $1.43 \pm 0.52^{\mathrm{d}}$ & $1.32 \pm 0.06^{\mathrm{e}}$ & $109.21 \pm 3.67^{\mathrm{d}}$ & $116.30 \pm 3.26^{\mathrm{d}}$ \\
\hline \multirow{4}{*}{4} & $\mathrm{~T} 3$ & ND & ND & ND & ND & ND & ND & ND \\
\hline & $\mathrm{T} 4$ & ND & ND & ND & ND & ND & ND & ND \\
\hline & $\mathrm{T} 5$ & ND & ND & ND & ND & ND & ND & ND \\
\hline & T6 & ND & ND & ND & ND & ND & ND & ND \\
\hline
\end{tabular}

Different letters denote $(\mathrm{p}<0.05)$ significant difference within each column, FHM= Freshly Harvested Maize, SD $=$ Storage Duration, T1 $=$ Undehusked maize, $\mathrm{T} 2=$ Dehusked maize, T3=Undehusked maize packaged with $25 \mu \mathrm{m}$ gauge LDPE, T4 = Dehusked maize packaged with $25 \mu \mathrm{m}$ gauge LDPE, T5= Undehusked maize packaged with $30 \mu \mathrm{m}$ gauge LDPE, T6 = Dehusked maize packaged with $30 \mu \mathrm{m}$ gauge LDPE, ND= Not Determined due to observations of microbial growth. Values are means $\pm \mathrm{SD}$ of three determinations.

\subsection{Sensory Qualities of Packaged and Unpackaged Fresh Maize on Cobs During Storage}

Presented in Table 4 are data on the sensory evaluation of boiled packaged and unpackaged storedmaize samples and freshly harvested maize on cobs. The sensory attributes of control sample in term of colour, taste, aroma and overall acceptability were significantly $(p<0.05)$ higher that the stored samples. However, unpackaged undehusked maize (T1) was preferred most and rated 5.85, 5.12, 4.86 and 3.25 for colour, taste, aroma and overall acceptability, respectively, on day 1 of storage. Decreases in panelists' scores were observed as the storage duration progressed. This showed that boiled stored fresh maize may be affected by temperature and duration of storage. This phenomenon suggests that the stored fresh maize on the cob lost sugar over the storage duration at different temperature conditions. The finding is in agreement with the result of [8] who also experience decrease in rated scores as the storage duration progressed. Taste, aroma and overall acceptability of the packaged samples were not evaluated on day 4 of storage due to the observations of microbial growth. 
Table 4. Sensory evaluation of packaged and unpackaged boiled fresh maize stored at $28 \pm 2{ }^{\circ} \mathrm{C}$.

\begin{tabular}{|c|c|c|c|c|c|c|c|c|}
\hline \multirow{2}{*}{$\begin{array}{l}\text { Sensory } \\
\text { attribute }\end{array}$} & \multirow{2}{*}{$\begin{array}{l}\text { SD } \\
\text { (day) }\end{array}$} & \multirow[t]{2}{*}{ FHM } & \multicolumn{6}{|c|}{ Storage treatments } \\
\hline & & & T1 & T2 & T3 & T4 & T5 & T6 \\
\hline \multirow{3}{*}{ Colour } & 1 & $8.22 \pm 0.34^{\mathrm{a}}$ & $5.85 \pm 0.17^{\mathrm{b}}$ & $5.11 \pm 0.28^{\mathrm{e}}$ & $5.35 \pm 0.35^{\mathrm{c}}$ & $5.10 \pm 0.30^{\mathrm{e}}$ & $5.21 \pm 0.52^{\mathrm{d}}$ & $4.96 \pm 0.62^{\mathrm{e}}$ \\
\hline & 2 & $8.61 \pm 0.22^{\mathrm{a}}$ & $5.61 \pm 0.40^{\mathrm{b}}$ & $4.11 \pm 0.43^{\mathrm{f}}$ & $3.22 \pm 0.40^{\mathrm{g}}$ & $3.07 \pm 0.52^{\mathrm{h}}$ & $3.18 \pm 0.36^{\mathrm{h}}$ & $2.95 \pm 0.54^{\mathrm{h}}$ \\
\hline & 4 & $7.95 \pm 0.28^{\mathrm{a}}$ & $4.85 \pm 0.31^{\mathrm{e}}$ & $3.42 \pm 0.52^{\mathrm{g}}$ & $1.30 \pm 0.05^{\mathrm{j}}$ & $1.12 \pm 0.05^{\mathrm{k}}$ & $1.26 \pm 0.05^{\mathrm{j}}$ & $1.15 \pm 0.05^{\mathrm{k}}$ \\
\hline \multirow{3}{*}{ Taste } & 1 & $8.82 \pm 0.61^{\mathrm{a}}$ & $5.12 \pm 0.72^{\mathrm{b}}$ & $3.84 \pm 0.39^{\mathrm{c}}$ & $3.66 \pm 0.48^{\mathrm{c}}$ & $3.46 \pm 0.55^{\mathrm{d}}$ & $3.36 \pm 0.63^{\mathrm{d}}$ & $3.51 \pm 0.44^{\mathrm{c}}$ \\
\hline & 2 & $8.65 \pm 0.61^{\mathrm{a}}$ & $3.04 \pm 0.31^{\mathrm{e}}$ & $2.23 \pm 0.29^{f}$ & $1.86 \pm 0.41^{\mathrm{g}}$ & $2.12 \pm 0.61^{\mathrm{f}}$ & $1.21 \pm 0.24^{\mathrm{h}}$ & $1.53 \pm 0.48^{\mathrm{g}}$ \\
\hline & 4 & $8.87 \pm 0.61^{\mathrm{a}}$ & $1.47 \pm 0.54^{\mathrm{g}}$ & $1.33 \pm 0.21^{\mathrm{h}}$ & ND & ND & ND & ND \\
\hline \multirow{3}{*}{ Aroma } & 1 & $8.58 \pm 0.51^{\mathrm{a}}$ & $4.86 \pm 0.62^{\mathrm{b}}$ & $3.81 \pm 0.55^{\mathrm{c}}$ & $3.20 \pm 0.23^{\mathrm{e}}$ & $3.41 \pm 0.55^{\mathrm{d}}$ & $3.16 \pm 0.26^{\mathrm{e}}$ & $3.18 \pm 0.27^{\mathrm{e}}$ \\
\hline & 2 & $8.61 \pm 0.51^{\mathrm{a}}$ & $2.11 \pm 0.63^{\mathrm{e}}$ & $1.65 \pm 0.33^{\mathrm{f}}$ & $1.45 \pm 0.71^{\mathrm{f}}$ & $1.55 \pm 0.28^{\mathrm{f}}$ & $1.12 \pm 0.49^{\mathrm{g}}$ & $1.24 \pm 0.25^{\mathrm{fg}}$ \\
\hline & 4 & $8.72 \pm 0.51^{\mathrm{a}}$ & $1.28 \pm 0.00^{\mathrm{fg}}$ & $1.20 \pm 0.04^{\mathrm{g}}$ & ND & ND & ND & ND \\
\hline \multirow{3}{*}{$\begin{array}{l}\text { Overall } \\
\text { acceptability }\end{array}$} & 1 & $8.31 \pm 0.44^{\mathrm{a}}$ & $3.25 \pm 0.57^{\mathrm{b}}$ & $3.05 \pm 0.57^{\mathrm{c}}$ & $2.21 \pm 0.33^{\mathrm{e}}$ & $2.46 \pm 0.36^{\mathrm{d}}$ & $1.98 \pm 0.27^{\mathrm{ef}}$ & $2.14 \pm 0.27^{\mathrm{e}}$ \\
\hline & 2 & $8.27 \pm 0.44^{\mathrm{a}}$ & $3.14 \pm 0.51^{\mathrm{c}}$ & $2.72 \pm 0.41^{\mathrm{d}}$ & $1.63 \pm 0.38^{\mathrm{f}}$ & $1.80 \pm 0.36^{\mathrm{f}}$ & $1.20 \pm 0.32^{\mathrm{g}}$ & $1.57 \pm 0.38^{\mathrm{f}}$ \\
\hline & 4 & $8.48 \pm 0.44^{\mathrm{a}}$ & $2.45 \pm 0.14^{\mathrm{d}}$ & $2.42 \pm 0.13^{\mathrm{d}}$ & ND & $\mathrm{ND}$ & ND & ND \\
\hline
\end{tabular}

Different letters denote significant $(\mathrm{p}<0.05)$ difference within each row. $\mathrm{SD}=$ Storage Duration, $\mathrm{FHM}=$ Freshly Harvested Maize, $\mathrm{T} 1=\mathrm{Undehusked} \mathrm{maize,} \mathrm{T} 2=$ Dehusked maize, T3=Undehusked maize packaged with $25 \mu \mathrm{m}$ gauge LDPE, T4= Dehusked maize packaged with $25 \mu \mathrm{m}$ gauge LDPE, T5=Undehusked maize packaged with $30 \mu \mathrm{m}$ gauge LDPE, T6= Dehusked maize packaged with $30 \mu \mathrm{m}$ gauge LDPE. ND= Not Determined due to observations of microbial growth. Values are means $\pm \mathrm{SD}$ of three determinations.

\section{Conclusions}

This research work was designed to reduce the postharvest loss in freshly harvested maize on the cob thereby increase the shelf life through appropriate storage conditions. Nutritionally, it can therefore be concluded that freshly harvested maize is a good source of carbohydrate (sugar) and minerals. The most abundant mineral in the fresh maize were potassium followed by phosphorus, sodium and magnesium. However, gradual decreases in nutrients were observed as the storage duration progressed. The results of this study showed that the tropical ambient temperature had significant effect on unpackaged undehusked and dehusked maize samples during storage while passive modified atmosphere packaging samples were greatly affected at this temperature.

\section{References}

[1] A. Ahmadi and P. Ziarati, "Chemical composition profile of canned and frozen sweet corn (Zeamays L.) in Iran," Oriental Journal of Chemistry, vol. 31, no. 2, pp. 1065-1070, 2015.

[2] E. T. Nuss and S. A. Tanumihardjo, "Maize: a paramount staple crop in the context of global nutrition," Comprehensive Review of Food Science and Food Safety, vol. 9, pp. 417-436, 2010.

[3] I. B. Oluwalana, "Comparative effects of sprouting on proximate, mineral composition and functional properties of white and yellow maize (Zea maysvarsaccharata)," Journal of Emerging Trends in Engineering and Applied Science, vol. 5, no. 7, pp. 111-115, 2014.

[4] J. E. Iken and N. A. Amusa, "Maize research and production in Nigeria," African Journal of Biotechnology, vol. 3, no. 6, pp. 302-307, 2004.

[5] R. A. Suleiman, K. A. Rosentrater and B. J. Carl, "Effects of deterioration parameters on storage of maize: a review," Journal of Natural Sciences Research, vol. 3, no. 9, pp. 147$168,2013$.
[6] W. Awoyale, B. Maziya-Dixon, O. E. Alamu and A. Menkir, "Effect of packaging materials and storage conditions on the degradation of xanthophylls in yellow-maize ogi powder," Journal of Food and Nutrition Research, vol. 4, no. 8, pp. 522$527,2016$.

[7] A. Junpatiw, K. Lertrat, K. Lomthaisong and R. Tangwongchai, "Effects of steaming, boiling and frozen storage on carotenoid contents of various sweet corn cultivars," International Food Research Journal, vol. 20, no. 5, pp. 2219-2225, 2013.

[8] P. More, T. Mhaske and S. Housalma, "Effects of packaging films on sensory aspects of fresh sweet corn kernels at different storage conditions," International Journal of Tropical Agriculture, vol. 33, no. 4, pp. 3661-3664, 2015.

[9] H. P. Geetha, V. Palanimuthu and B. Ranganna, A study on shelf-life extension of freshly harvested sweet corn cobs (Zea mays var. rugosa). Int. J. Proc. and Post Harvest Technol., vol. 5, no. 2, pp. 131-135, 2014.

[10] I. B. Oluwalana, "Minimizing fruit wastages in Nigeria," International Journal of Agriculture and Food Science, vol. 1, no. 1, pp. 77-87, 2010.

[11] P. V. Mahajan, O. J. Caleb, Z. Singh, C. B. Watkins and M. Geyer, "Postharvest treatments of fresh produce," Philosophical Transaction of the Royal Society A, vol. 372, pp. 1-19, 2014.

[12] AOAC, Official methods of analysis (18th Edn.), "Association of Official Analytical Chemists,"Washington, DC, USA, 2005.

[13] S. S. Nielsen, "Phenol sulphuric acid method for total carbohydrates," Food Analysis Laboratory Manual, Food Science Texts Series, pp 47-53, 2009.

[14] A. I. Ihekoronye and P. O. Ngoddy, Intergrated Food Science and Technology for Tropics. Macmillan, London. 1985, pp. 386.

[15] J. C. Rickman, D. M. Barret and C. M. Bruhn, "Review. Nutritional comparison of fresh, frozen, and canned foods and vegetables I. Vitamin C and B and phenolic compounds," Journal of the Science of Food and Agriculture, vol. 87, pp. 930-944, 2007a. 
[16] R. E. Hardenburg, A. E. Watada and C. Y. Wang, "The commercial storage of fruit, vegetables, and florist and nursery stock," Agricultural handbook. U.S. Department of Agriculture, Washington, D.C, 1986.

[17] D. Shobha, T. A. Sreeramasetty, Puttaramanaik and K. T. Pandurange Gowda, "Evaluation of maize genotypes for physical and chemical composition at silky and hard stage," Karnataka Journal of Agricultural Science, vol. 23, no. 2, pp. 311-314, 2010.

[18] K. B. Evensen and C. D. Boyer, "Carbohydrate composition and sensory quality of fresh and stored sweet corn," Journal for the American Society for Horticultural Science, vol. 111, pp. 734-738, 1986.

[19] J. K. Olsen, J. E. Giles and R. A. Jordan, "Post-harvest carbohydrate changes and sensory quality of three sweet corn cultivars," Scientia Horticulturae, vol. 44, no. 3-4, pp. 179$189,1990$.
[20] V. M. Ghorpade, M. A. Hanna and S. J. Jadhav, "Sweet corn. Handbook of vegetable science and technology, production, composition, storage and processing," Salunkhe, D. K. and Kadam, S. S. (Editors). Marcel Dekker, Inc, New York, NY, vo. 27,1998 , pp. 609-646.

[21] B. Kara, A. Ertek and B. Arar, "Mineral Nutrient Content of Sweet Corn under Deficit Irrigation," Journal of Agricultural Sciences, vol. 22, pp. 54-61, 2016.

[22] B. M. John and R. W. Jeanne, "Human health, the nutritional quality of harvested food and sustainable farming systems," http://www.nutritionsecurity.org/PDF/NSI_White\%.pdf (accessed September 2012).

[23] I. B. Oluwalana and M. O. Oluwamukomi, "Changes in qualities of ripening plantains fruits stored at tropical ambient conditions," International Journal of Agriculture and Food Science, vol. 1, no.1, pp. 203-207, 2010. 